\title{
Article \\ Challenges and Opportunities for Technology Transfer Networks in the Context of Open Innovation: Russian Experience
}

\author{
Nadezhda Shmeleva ${ }^{1}\left(\mathbb{D}\right.$, Leyla Gamidullaeva ${ }^{2,3, *(D)}$, Tatyana Tolstykh ${ }^{4,5}$ (D) and Denis Lazarenko 6 \\ 1 Department of Economics, National University of Science \& Technology (MISIS), 119049 Moscow, Russia; \\ nshmeleva@misis.ru \\ 2 Department of Economics and Management, Penza State University (PSU), 440026 Penza, Russia \\ 3 Department of Applied and Business Informatics, K.G. Razumovsky Moscow State University of \\ Technologies and Management (FCU), 109004 Moscow, Russia \\ 4 Department of Industrial Management, National University of Science \& Technology (MISIS), \\ 119049 Moscow, Russia; tt400@mail.ru \\ 5 Department of the Digital Economy and Information Technologies, Plekhanov Russian University of \\ Economics, 119049 Moscow, Russia \\ 6 Institute of Economics and Industrial Management, National University of Science \& Technology (MISIS), \\ 119049 Moscow, Russia; lazarenkodg@yandex.ru \\ * Correspondence: gamidullaeva@gmail.com
}

Citation: Shmeleva, N.;

Gamidullaeva, L.; Tolstykh, T.;

Lazarenko, D. Challenges and

Opportunities for Technology

Transfer Networks in the Context of

Open Innovation: Russian Experience.

J. Open Innov. Technol. Mark. Complex.

2021, 7, 197. https://doi.org

/10.3390/joitmc7030197

Received: 14 July 2021

Accepted: 30 August 2021

Published: 3 September 2021

Publisher's Note: MDPI stays neutral with regard to jurisdictional claims in published maps and institutional affiliations.

Copyright: (c) 2021 by the authors. Licensee MDPI, Basel, Switzerland. This article is an open access article distributed under the terms and conditions of the Creative Commons Attribution (CC BY) license (https:// creativecommons.org/licenses/by/ $4.0 /)$.
Abstract: Nowadays, the relevance of technology transfer center network has been greatly increased due to interdisciplinary modern innovations, and cross-sectoral collaboration in project implementation. This paper highlights theoretical and conceptual foundations of technology transfer, and the role of innovation and knowledge. The main purpose of the paper is to analyze the experience of creating technology transfer networks in Russia, and to develop prospective national technology transfer model based on the concept of innovation ecosystem and open innovation. Being a knowledge integrator, a university plays a vital role in technology transfer. The presented study makes contribution to the academic literature by providing a synthesis on related concepts of open innovation, network, and ecosystem approaches to technology transfer. The results of this analysis provide information on prospective models for creating a network of technology transfer in Russia. That will help academics, policymakers, government, and business owners with a more depth understanding of the practical mechanisms that support innovation strategy.

Keywords: technology transfer; network models; innovation ecosystem; technological cooperation; open innovation; cross-sectoral collaboration; clusters

\section{Introduction}

Implementation of efficient technological transfer is gaining strategic importance under the current conditions of accelerated transformation of socio-economic processes caused by rampant technological development. In such an environment, technology transfer (TT) becomes an important factor for improving companies' competitiveness through technological advancement and innovations [1], and contributes to socio-economic development of regions and countries [2].

There are various TT models presented and evaluated in the literature [3-5]. However, in response to criticisms of linear models [6], the network approach to technology transfer is viewed as a globally recognized trend and a requisite for modern successful technology transfer. In this approach, technology transfer means the transfer of an innovative solution from one entity to another by applying various non-linear and dynamic communication links. It facilitates the transition of an innovative resource and acts as a link between innovative activities. To implement technology transfer, an organization should create 
a network (or an innovation ecosystem) of external partners (actors) having expertise in the required technologies. In these networks, the importance of technology transfer centers (TTC) is crucial, being greatly increased nowadays, when it is necessary to focus on interdisciplinary nature of modern innovations and cross-sectoral collaboration in project implementation.

Rapid technological and market development and growing demand to enhance competitiveness in global economic space create specific requirements for the formation of an innovative business environment. Being the main goal of any business, the process of creating value can be carried out by enterprises independently, but in order for this process to be innovative, active links with the external environment are required. The growing importance of collaboration and networking for innovative development has been emphasized by E. von Hippel, H. Chesbrough, and M. Bogers [7-9]. Besides, the emergence of digital technologies and platforms has significantly expanded opportunities for creation of networks and collaboration, and the growth of open socio-economic systems.

In addition, most novel end-to-end technologies require the involvement of a wide variety of participants with different competencies in the process of developing innovations. The key strategy therein should be an interaction of subjects in various sectors of the economy (the so-called cross-sectoral or inter-sectoral interaction) through the creation of new business models and end-to-end business processes at the intersection of industries, and through cross-border cooperation [10]. A major requirement for the formation and successful implementation of cross-sectoral projects is the presence of a project initiator who is most interested in its successful execution, as well as a friendly environment that provides free access to market, knowledge and information, as well as to financial and other types of support [11].

Searching for organizational and managerial models that ensure innovative development through interaction with the external environment has been going on for decades. In recent years, the scientific community has been actively exploring another model of enterprise interaction called an innovation ecosystem. However, the innovation ecosystem model is not efficient enough in Russian conditions. It transforms into quasi-ecosystems due to disunity among actors, disagreement of their interests, lack of internal and external communications that form the basis of ecosystem interaction and are a source of positive synergistic effects of cooperation and collaboration of network interaction participants.

Modern economy is called an economy of ecosystems [11]. Particular attention is paid to the organization of interaction both between actors of a separate ecosystem, and between actors of various ecosystems, and between the ecosystems themselves in general. This is consistent with an extensive strategic course of development, namely, the formation of a common innovative economic space, or a national innovation ecosystem in our country. The national innovation ecosystem indicates the level of collaboration between different participants (individual actors, groups of actors, and ecosystems), which jointly form the country's ability to produce innovations.

Research into cooperation between scientific and industrial sectors as a phenomenon that accelerates innovation processes is carried out by various research organizations [12-18]. Most of these studies have been focused on mechanisms for commercialization of academic research, namely, patenting, licensing of innovations, or creating enterprises based on novel technologies [12,14-16].

Implementation effectiveness of innovations directly depends on the efficiency of technology transfer, since the latter is the initial stage of the innovation process, influencing all subsequent stages of its implementation [19-23]. Technology transfer involves transfer of innovation-driven development from one subject to another [24] via various communication channels, and facilitates the transit of an innovative resource and acts as a link in innovation activity.

To implement a technology transfer project in a company, there is a demand to create an innovation ecosystem of external partners with expert knowledge in this technological area. 
In modern conditions, instead of building own network, innovative companies increasingly rely on intermediaries and platforms that connect the company with external partners. Such professional innovative intermediaries, united by a unified methodology within the network, having grown into TTC, greatly increase the efficiency of search for a technology partner compared to the situation when they operate in isolation, relying only on their own resources.

The present study is devoted to the analysis of these issues in the context of Russian policy having encouraged the creation of links between science and industry for dozens of years. However, these efforts have not led to positive outcomes: transfer of skills between participants involved in research and commercial projects is still insufficient; dissemination of knowledge is insignificant; technology transfer is characterized by low demand and efficiency. In turn, it is the transfer of technology to be the most important driving force for innovations to ensure sustainable economic growth [25].

That is why we will focus on the analysis of existing organizational mechanisms and approaches to provide the interaction between participants in innovation ecosystems. The latter contribute to an increase in the efficiency of coordination of links between science and the real sector of the economy, ensuring the persistence of technology transfer processes as a foundation for the development in terms of interdisciplinary innovations.

Currently, the role of TTC network has been increased many times over to focus on interdisciplinary modern innovations and cross-sectoral collaboration in project implementation. Russian TTC networks involve careful research and analysis in view of modern trends and concepts of innovative development. The latter imply the concept of innovation ecosystem and open innovation. In modern Russia, it appears necessary to analyze the practice of building technology transfer networks, and to investigate the barriers that prevent effective technology transfer within various innovative ecosystems.

This will enable to determine promising development areas and forms for technology transfer networks in Russia, and to contribute to the solution of the previously mentioned key research problem, namely, increasing the connectivity of the innovation economic space of our country, and the formation of integrated national innovation ecosystem.

Thus, the main purpose of the paper is to analyze existing barriers for technology transfer at different levels in Russia and propose prospective models and solutions for TT development taking into account recent concepts of innovation ecosystem and open innovation.

The authors' contribution to TTC networks development consists in solving the following main tasks:

- Make a review of TT theoretical and conceptual foundation;

- Make an analysis of TTC practice in Russia and identify existing barriers for technology transfer;

- Develop criteria for analyzing TTC networks models at meso- and macro levels;

- Identify main features of innovation ecosystems;

- Make an analysis of existing barriers for technology transfer at different levels;

- Propose models and solutions for TT development based on ecosystem and open innovation concepts.

The research results contribute to the literature by providing a synthesis on the above concepts applied to the problem of technology transfer. That will also help academics, policymakers, governments, and business owners with a more depth understanding of the practical mechanisms that support innovation strategy in the open innovation perspective.

The paper is organized as follows. First, regarding a theoretical overview of technology transfer, related schools of thought are provided. Section 3 introduces the assessment of the current situation regarding technology transfer in Russia. Section 4 presents an analysis of the existing barriers with a particular focus on solutions for their overcoming. In Section 5, the authors make some concluding remarks and discuss prospective models for creating a network of technology transfer centers. The key findings of the study, its theoretical contribution and practical significance are highlighted. The constraints of the research and pathways for further research are also suggested. 


\section{Literature Review}

Formation and practical implementation of an ecosystem model will provide for creation of an intelligent environment to actualize breakthrough technologies based on network partnership, transboundary and cognitive principles [11]. Ecosystems can be formed on different unifying principles (from geographic and political, to production and environmental), as well as at different levels: from local (within organizations, companies, clusters, and science parks) to global, that is, wherever stable relationships and shared vision of the participants emerge [12]. An ecosystem cannot be strictly linked to specific business or production sector, but brings together interconnected enterprises from a variety of industries that jointly seek to create differentiated proposals and to extract value that they could not get alone.

Conceptual foundations of innovation ecosystems are laid in studies of regional innovation systems, which emphasize the relationship between formal and informal institutions and innovations. In our opinion, a rather comprehensive definition of an innovation ecosystem has been lately formulated in [13]: "An innovation ecosystem is the evolving set of actors, activities, and artifacts, and the institutions and relations, including complementary and substitute relations that are important for the innovative performance of an actor or a population of actors".

Generally recognized and widely discussed open innovation concept proposed by Chesbrough [7], based on the previous theory of open systems by R. E. Quinn and J. Rohrbaugh, is crucial for our research [14]. The concept of open innovations explains how to extract values from technologies and argues the possibility of its maximizing using external sources. Research and developments make up most of the knowledge needed to create innovations [15]. The ability to learn, perceive, and use new knowledge faster than competitors is turned into the most important competitive advantage.

The concept of open innovations [7] allows overcoming geographic, institutional, and disciplinary barriers due to the openness of R\&D, diffusion of technologies, knowledge exchange between universities, research laboratories, engineering centers, suppliers, consumers, and technology transfer centers. The key principle of open innovations is the use of external ideas and technologies that reduce R\&D cost and time, while improving the overall efficiency of the company.

Professor Chesbrough formulated his theory in his book Open Innovation: The New Imperative for Creating and Profiting from Technology [9]. Chesbrough argues that in modern economy focused on information and technology, obsolete methods of innovation management are not effective enough. He refers to them as "closed innovation". Enterprises were guided by these methods throughout the twentieth century, when the process of integration and globalization had not yet reached modern proportions, and most of the issues related to attracting and managing innovations had to be solved independently within the enterprise [26].

In these conditions, the company received the greatest profit if it had attracted the largest number of specialists and coped with the entire innovation process from R\&D to bringing the finished product to the market the best way possible. As a new paradigm for "open innovation," Chesbrough proposes "to innovate innovation," as articulated by J. S. Brown from Xerox Corporation in his foreword to Chesbrough's book. Companies no longer need to develop ideas and conduct research themselves, because this process has been left to startup companies, universities, and other intermediaries. The company itself only needs to accurately look for the prospects in an innovative project, offer the best business model for its implementation, and work properly with the external environment.

Chesbrough believes that in the modern economy, the catalysts for innovative development are outside enterprises. Sure, the sectors related to defense and strategic objectives of states remain closed, but other sectors are in transition to a new innovation paradigm.

Creation of innovative technologies and conducting research in these industries moves from R\&D labs within enterprises to widespread startup companies, universities, and intermediaries. The latter are discussed in more detail in Chesbrough's book Open Busi- 
ness Models: How to Thrive in the New Innovation Landscape [27]. Chesbrough describes intermediaries as a new phenomenon in the market and introduces the concept of "innovation intermediaries".

Innovation intermediaries have emerged from the development of the intellectual property market, and are engaged in supporting innovative activity. Their key task is to provide access to global innovation resources and to form a global society of innovation providers. Chesbrough cites several examples of their activity, such as InnoCentive Company, which provides an online portal for information exchange, thereby creating a market for technology exchange.

As is known, the main areas of technological transfer are direct and indirect technology transfer (Figure 1). Direct technological transfer is transfer of science-intensive development from its author (owner) to the subject of industrial production. Both inventors and specialists from the company buying the technology participate in this form of technology transfer. Indirect technological transfer has resulted from the development of the open innovation concept. It is a process with the key subject being an intermediary between an innovator and a production organization.

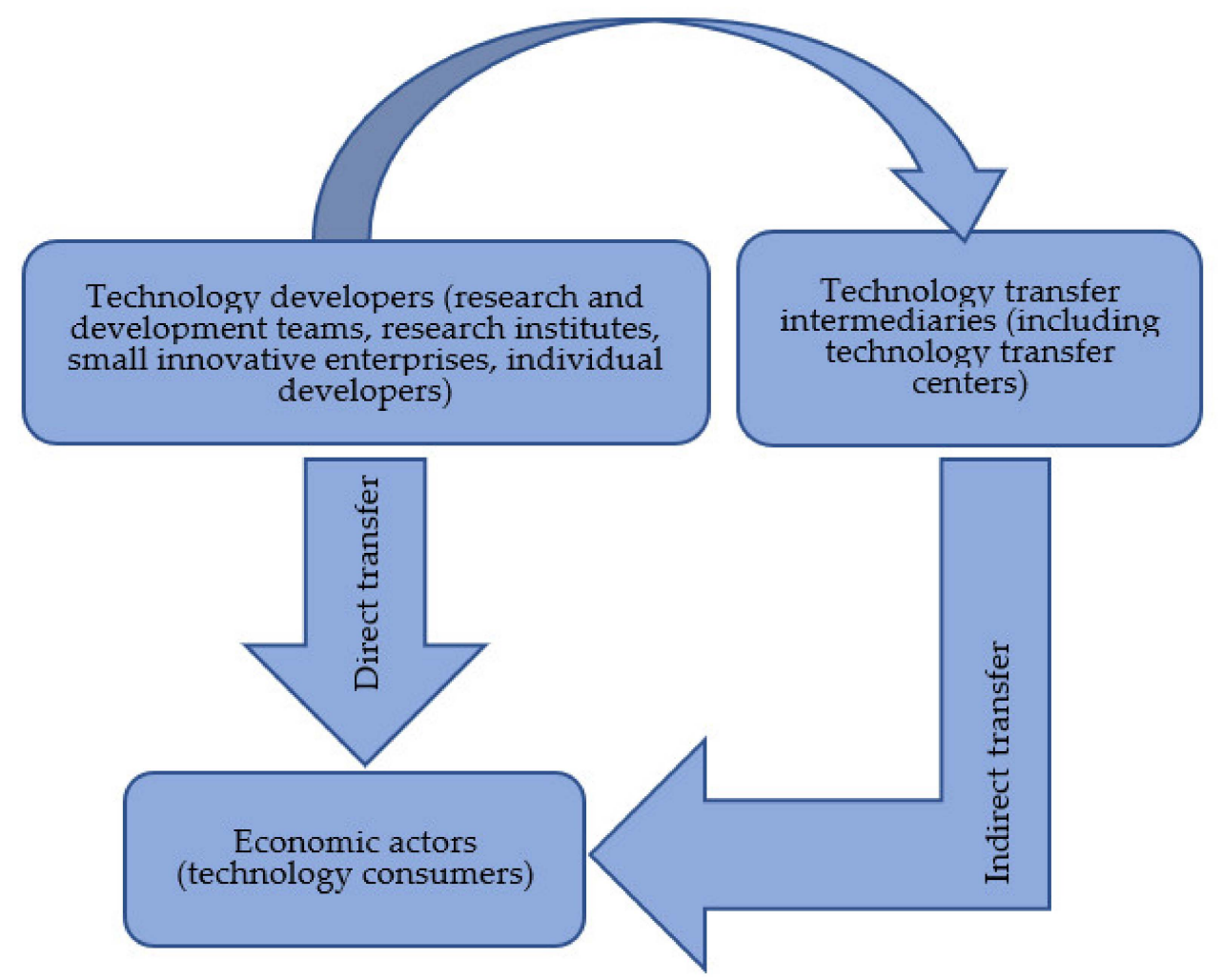

Figure 1. Types of technology transfer. Source: own elaboration (based on [28]).

Open innovations $[7,27]$ are based on the following statements:

- Transition from the use of exclusively internal closed developments to the use of external knowledge;

- There are many ideas on the market that may bring profit to the company;

- Creation of a sustainable organizational business model is a priority in comparison with leadership in the market;

- It is necessary to effectively use both internal and external ideas, and developments.

The concept of open innovation is a kind of advancement in practice and methodology of technology transfer, expanding thereof to knowledge transfer and allowing a systematic look at the company's business model, considering the development of innovative products.

Universities play a key role in this process. The idea of transferring research results from universities to the economic sector was first expressed by Vannevar Bush in his 
1945 report to the President of the United States entitled Science: The Endless Frontier. The report spurred significant research funding from the federal government, which led to the establishment of several government structures directed at research, for example, the National Science Foundation, the Office of Naval Research, etc.

Although technology transfer is not a new business phenomenon, it is difficult to give a specific and unambiguous definition thereof due to internal process complexity $[29,30]$.

The definitions of TT depend on how and in what context the user considers technology, since technology transfer can be interdisciplinary, can take place in any field and at the intersection of different industries [31]. Technology transfer is a special and complex type of communication process subject to regulatory and legal support, and the development of appropriate policies. Technology transfer is both the introduction of innovations in another organization, and novel application of the technology by a different user [29]. In addition, transfer can refer to technology, technique or knowledge being developed in one company and then transferred to another, where they are successfully used [30]. Technology transfer is an exchange process between the inventor (owner of the technology) and the recipient (initiator of the innovation), accompanied by production functions (adaptation of the product for the production process) in cases of performing additional R\&D, design and survey, and other types of work, allowing them to reduce transaction costs and create added value [31].

There are many basic characteristics of technology transfer that emerge from the above definitions:

(1) A technology comprises several elements, measurements, and components. Numerous components of technology, considered in each case, interact with each other on the basis of systemic principles. Technology transfer is a dynamic process, since technologies are periodically re-evaluated, and changes thereof are monitored as new information becomes available;

(2) An appropriate environment (formal institutions) is necessary for effective technology transfer, which involves various stakeholders, for example, scientific institutions, R\&D facilities, educational institutions, government authorities, etc. Besides, this requires an acceptable cultural environment (informal rules, habits, patterns of behavior and interaction between subjects) [32]. Both infrastructure and cultural environment are major determinant factors of effective technology transfer;

(3) Technologies developed in a certain specific context have to be changed and further developed (e.g., changing the scale of the production process, modifying products) in order to adapt to characteristics of the local market.

An impetus to the process for technology transfer is set by the investment and industrial demand for innovation, which is satisfied through the economic mechanism of the market and the corresponding innovation ecosystem.

In technology transfer, the main emphasis is on the actors involved in the implementation of this process rather than on technologies. Each actor participating in the technology transfer influences the intensity of transfer and the assurance of bringing innovation to the stage of industrial development, contributing to the process of the evolutionary development of technology in the form of economic resources and services [31].

Technology transfer, which is the initial stage of the innovation process, ensures the continuity of information transfer at all stages of the innovation process, which is a strategically important requirement for the effective innovation activity of high-technology enterprises.

At present, different approaches to open innovation are used by various TTC along with other subjects of technology transfer, such as science and technology parks, consulting organizations, innovation relay centers, technology platforms, investment and financial centers, coaching centers for venture financing and entrepreneurship [33,34].

TTC is a specialized organization created on its own as a legal entity or as a structural unit of a large educational, research, and industrial organization to provide consulting and other support to developers of innovative technologies and products in the implementation of their further transfer, implementation and development, as well as assistance in estab- 
lishing contacts between research and production entities at the national and international level [31].

Moreover, the concept of open innovation has stimulated the emergence of new instruments, for example, technology marketplaces based on the crowdsourcing methodology. The prospects for using this concept and its tools should be considered when creating technology transfer center networks.

The networking approach to technology transfer is a generally recognized global trend. To implement a technology transfer project, an organization should create a network (or innovation ecosystem) of external partners (actors) with expert knowledge in the required technologies.

In modern Russia, it is vital to analyze practice of creating technology transfer networks in order to identify the existing models of technology transfer, reveal functions performed by technology transfer centers, and analyze barriers that impede the effective technology transfer within the framework of innovation ecosystems of various level and industries.

Existing TTC network models such as technology brokers network, technology marketplace, TTC [35-41] created as special projects do not provide a full innovation cycle and integration of participants actions in the innovation process. The model proposed by the authors, based on the ecosystem approach, provides a complex of cooperation between actors in the process of creating added value in the innovation production. Innovation ecosystems provide opportunities for cross-industry collaboration, creating connections in networks, minimizing transaction costs and the innovation cycle duration. In this way, the ecosystem model contributes to overcoming existing barriers to TTC network implementation and increasing the efficiency of their functioning. Consequently, it would be reasonable to develop prospective national technology transfer model based on the concept of innovation ecosystem and open innovation approach.

\section{An Analysis of Technology Transfer Practice in Russia}

The Russian Federation is recognized for a remarkable scientific innovation potential, demonstrates notable results and achievements in the field of nano- and bio-technologies, nuclear energy, aerospace technologies, communications facilities, and information technologies. The scale of the Russian consumer market potentially makes it possible to develop a production system directed at the consumption of competitive innovative products. There are main subsystems of the national innovation system (NIS) in the country with created institutions for innovative development (though their activities are insufficiently coordinated). In spite of development of various scientific and technical organizations in the system of innovation infrastructure (technoparks, clusters of innovative technologies, certification and commercialization centers, venture business, university science, etc.), it is not enough for a collaborative effect to form an integral successful model of the country's NIS.

There is a significant gap in innovative development compared to the developed countries nowadays. For example, according to the Global Innovation Index [34], Russia ranked 47th place among 131 states in 2020.

Besides, there is a decrease in the number of transactions in relation to the transfer of exclusive rights to objects of intellectual property (inventions, utility models, industrial designs) under contracts registered in the territory of the Russian Federation. Only one license agreement accounts for an average of 16 issued patents.

The main reasons for the gap in innovative development are the low level of innovation and investment activity of private business, insufficient financing of the innovation sphere, weak interaction of R\&D sector with the real sector of the economy, and the openness of the innovation cycle.

In order to ensure the growth of the country's economy, it is necessary to form an effective communication system in the field of science, technology, and innovation, to increase the susceptibility of the economy and society to innovations, and develop science- 
intensive business. This can be only achieved by combining the efforts of all stakeholders, through the integration of innovative, human, and scientific and technical potentials.

According to the National Information and Analytical Center for Monitoring the Innovation Infrastructure of Scientific and Technological Activities and Regional Innovation Systems, 105 technology transfer centers are registered in Russia (as of 2019). Most micro-level TTC are created at universities with the aim of promoting the development of innovative activities and the formation of conditions for effective interaction between the university and industry.

In Russia, the key role in state support for the technology transfer process is played by structures included in the so-called development institutions, being state policy instruments that stimulate innovation processes and infrastructure development. The main actors are the Russian Venture Company (RVC JSC), the Russian Corporation of Nanotechnologies (RUSNANO JSC), the Innovation Promotion Fund, and the Skolkovo Foundation. The main goal of development institutions is to overcome the so-called "market failure" to solve problems that cannot be optimally implemented by market mechanisms, to ensure sustainable economic growth and diversification of the economy. Their activities in the field of technology transfer support differ both in thematic priorities, and target groups of potential support recipients. In May 2016, the Agency of Technological Development was founded by the decision of the Government of the Russian Federation aimed at creating conditions for domestic and foreign technology transfer, and developing hightech production of industrial products in the territory of the Russian Federation. Several initiatives to implement technology transfer network models were taken in the Russian Federation from 2000 to 2020 (Table 1).

Table 1. An analysis of Russian technology transfer network models at meso- and macro-levels.

\begin{tabular}{|c|c|c|c|c|c|}
\hline \multirow[b]{2}{*}{$\begin{array}{l}\text { Criteria for } \\
\text { analysis }\end{array}$} & \multicolumn{5}{|c|}{ Russian Innovative Technology Transfer Networks } \\
\hline & $\begin{array}{c}\text { Russian Technology } \\
\text { Transfer Network } \\
\text { (RTTN) }\end{array}$ & $\begin{array}{c}\text { National Network } \\
\text { of Technology and } \\
\text { Innovation Support } \\
\text { Centers (TISCs) }\end{array}$ & $\begin{array}{c}\text { Russian Union of } \\
\text { Innovation and } \\
\text { Technology Centres } \\
\text { (RuITC) }\end{array}$ & $\begin{array}{c}\text { Network of } \\
\text { Technology Transfer } \\
\text { Centers of the } \\
\text { Russian Academy of } \\
\text { Sciences (RAS) and } \\
\text { RUSNANO }\end{array}$ & $\begin{array}{c}\text { Enterprise Europe } \\
\text { Network } \\
\text { (EEN)-Russia } \\
\text { Consortium }\end{array}$ \\
\hline \multicolumn{6}{|c|}{ Organizational aspects } \\
\hline $\begin{array}{l}\text { Network } \\
\text { goals and } \\
\text { objectives }\end{array}$ & $\begin{array}{l}\text { Assistance in the } \\
\text { development of } \\
\text { innovative business } \\
\text { and } \\
\text { commercialization } \\
\text { of science-intensive } \\
\text { technologies in } \\
\text { Russia. Network } \\
\text { objectives: } \\
\text { technology transfer } \\
\text { between scientific } \\
\text { sector and } \\
\text { innovative } \\
\text { companies, and } \\
\text { search for partners }\end{array}$ & $\begin{array}{l}\text { A joint project of } \\
\text { Rospatent and the } \\
\text { World Intellectual } \\
\text { Property } \\
\text { Organization } \\
\text { (WIPO) aimed at } \\
\text { the development of } \\
\text { intellectual } \\
\text { property in Russia } \\
\text { and worldwide }\end{array}$ & $\begin{array}{l}\text { Implementation of } \\
\text { activation policy for } \\
\text { entrepreneurial, and } \\
\text { scientific and } \\
\text { technical activities; } \\
\text { assistance in the } \\
\text { creation of novel } \\
\text { innovative } \\
\text { enterprises and } \\
\text { support for existing } \\
\text { ones; organization of } \\
\text { interaction between } \\
\text { scientific, educational, } \\
\text { innovative } \\
\text { organizations, and } \\
\text { business }\end{array}$ & $\begin{array}{c}\text { Transfer of } \\
\text { knowledge and } \\
\text { technologies between } \\
\text { RAS research } \\
\text { institutes, JSC } \\
\text { RUSNANO, and } \\
\text { business in the field } \\
\text { of nanotechnologies }\end{array}$ & $\begin{array}{c}\text { Support for } \\
\text { international, } \\
\text { interregional } \\
\text { business, and } \\
\text { scientific and } \\
\text { technical cooperation }\end{array}$ \\
\hline
\end{tabular}


Table 1. Cont.

\begin{tabular}{|c|c|c|}
\hline $\begin{array}{c}\text { Network } \\
\text { participants }\end{array}$ & $\begin{array}{l}\text { Over } 50 \text { innovation } \\
\text { centers from } 40 \\
\text { regions of Russia } \\
\text { and the CIS } \\
\text { countries } \\
\text { specializing in } \\
\text { technology transfer }\end{array}$ & $\begin{array}{l}\text { About } 170 \text { regional } \\
\text { centers }\end{array}$ \\
\hline
\end{tabular}
Twenty-three RuITC and innovation infrastructure organizations from nine constituent entities of the Russian Federation

Foundation for Assistance to Small Innovative

Enterprises; Russian

Union of Innovation and Technology

Eighty RAS institutes, RUSNANO,

Centres; Russian

Skolkovo Foundation

Agency for Support of Small and Medium-sized

Businesses. Coverage of over 60 regions of the Russian Federation

$\begin{array}{cc}\begin{array}{c}\text { Year of } \\ \text { establishment }\end{array} & 2002 \\ & \begin{array}{c}\text { Innovative } \\ \text { companies, } \\ \text { scientific and } \\ \text { educational } \\ \text { organizations } \\ \text { oudience }\end{array} \\ \begin{array}{cc}\text { Network } \\ \text { model }\end{array} & \begin{array}{c}\text { Distributed model. } \\ \text { Each center } \\ \text { provides }\end{array} \\ & \begin{array}{c}\text { technology transfer } \\ \text { services to clients in } \\ \text { its region }\end{array}\end{array}$

2012
Commercial
companies,
individual
entrepreneurs,
scientific and
educational
organizations
Distributed model.
Presence of
three-level centers
with diverse tasks
and types of
activities

$\begin{array}{cc}2000 & 2014 \\ \begin{array}{c}\text { Scientific } \\ \text { organizations, } \\ \text { technoparks, industry } \\ \text { research institutes, } \\ \text { universities. }\end{array} & \begin{array}{c}\text { Organizations } \\ \text { engaged in } \\ \text { innovative projects in } \\ \text { the field of } \\ \text { nanotechnologies }\end{array}\end{array}$

2008

Small and medium-sized enterprises, research organizations and teams, private developers
Technology broker Specialized (thematic) network technology transfer network
Transnational technology transfer network

\begin{tabular}{cc} 
& its region \\
\hline & \\
Network & $\begin{array}{c}\text { Entry is possible via } \\
\text { entry }\end{array}$ \\
passing a special \\
mechanisms & certification \\
procedure
\end{tabular}

Intra-network
building tools Technology
brokerage
Functional characteristics

\section{Voluntary}

membership based

on the statement of

the head of the organization
Voluntary

membership via

registration and
Competitive selection

based on the results and investment expertise of innovative projects

Creation of project companies together with nanocenters of RUSNANO Fund for Infrastructure and Educational

Programs, RAS and

Skolkovo research institutes in common events. Crowdsourcing international internationa international conferences; business schools; business missions; exhibitions. application system

of scientific, technical

Special competitive selection by the

Executive Agency for Small and

Medium-Sized Enterprises (EASME)

Technology

marketplace, brokerage events, personal contacts, special projects initiated by network members

Safety Advisory Group (SAG). Operational management is carried out by EASME

is federal Institute of Industrial Property (Rospatent)
Management committees
Fund for Educational Programs

\begin{tabular}{|c|c|c|c|c|c|}
\hline IT platform & $\begin{array}{l}\text { RTTN } \\
\text { Information } \\
\text { Technology } \\
\text { Platform }\end{array}$ & $\begin{array}{l}\text { WIPO INSPIRE and } \\
\text { Rospatent } \\
\text { Platform }\end{array}$ & $\begin{array}{l}\text { Unified Information } \\
\text { Communication } \\
\text { System (ICS) } \\
\text { integrated into } \\
\text { EASME }\end{array}$ & $\begin{array}{c}\text { RUSNANO } \\
\text { Information } \\
\text { Technology Platform }\end{array}$ & Merlin IT Platform \\
\hline \multicolumn{6}{|c|}{ Strategic development } \\
\hline $\begin{array}{l}\text { Financial } \\
\text { conditions }\end{array}$ & $\begin{array}{l}\text { Lack of systematic } \\
\text { financing of the } \\
\text { network. } \\
\text { Project-based } \\
\text { support through } \\
\text { national and } \\
\text { international } \\
\text { programs }\end{array}$ & $\begin{array}{l}\text { Providing free and } \\
\text { paid services. } \\
\text { Support through } \\
\text { national and } \\
\text { international } \\
\text { programs }\end{array}$ & $\begin{array}{l}\text { Non-profit } \\
\text { organization. } \\
\text { Support is provided } \\
\text { through government } \\
\text { programs }\end{array}$ & $\begin{array}{c}\text { TTC does not provide } \\
\text { grants. The key } \\
\text { project investor is } \\
\text { RUSNANO } \\
\text { nanocenter network }\end{array}$ & $\begin{array}{l}\text { Provision of services } \\
\text { to small and } \\
\text { medium-sized } \\
\text { enterprises for free } \\
\text { (subsidized under the } \\
\text { Programme for the } \\
\text { Competitiveness of } \\
\text { Enterprises and Small } \\
\text { and Medium-Sized } \\
\text { Enterprises (COSME) }\end{array}$ \\
\hline
\end{tabular}


Table 1. Cont

\begin{tabular}{|c|c|c|c|c|c|}
\hline $\begin{array}{c}\text { Competitive } \\
\text { advantages } \\
\text { for } \\
\text { sustainability }\end{array}$ & $\begin{array}{l}\text { Use of the adapted } \\
\text { European } \\
\text { technology transfer } \\
\text { methodology }\end{array}$ & $\begin{array}{l}\text { Use of the world's } \\
\text { best practices and } \\
\text { access to WIPO } \\
\text { resources. Free } \\
\text { training on } \\
\text { educational } \\
\text { programs of } \\
\text { network partners. } \\
\text { Developed regional } \\
\text { network }\end{array}$ & $\begin{array}{l}\text { Highly qualified } \\
\text { certified experts. } \\
\text { Multidisciplinary } \\
\text { services and } \\
\text { comprehensive } \\
\text { support for } \\
\text { innovative companies }\end{array}$ & $\begin{array}{l}\text { Corporate accelerator, } \\
\text { innovative consulting, } \\
\text { technology scouting. } \\
\text { Ecosystem of the } \\
\text { innovation process }\end{array}$ & $\begin{array}{c}\text { Presence of an } \\
\text { internal } \\
\text { motivation of small } \\
\text { and medium-sized } \\
\text { enterprises to } \\
\text { improve } \\
\text { competitiveness } \\
\text { through technology } \\
\text { transfer and } \\
\text { internationalization. } \\
\text { EU support. }\end{array}$ \\
\hline $\begin{array}{c}\text { Networkization } \\
\text { level }\end{array}$ & $\begin{array}{l}\text { Participation in } \\
\text { EEN and Innoget }\end{array}$ & $\begin{array}{l}\text { Participation in } \\
\text { WIPO, federal } \\
\text { network of centers }\end{array}$ & $\begin{array}{c}\text { Participant: } \\
\text { Enterprise Europe } \\
\text { Network (EEN), } \\
\text { International } \\
\text { Network for Small } \\
\text { and Medium-Sized } \\
\text { Enterprises (INSME) }\end{array}$ & $\begin{array}{l}\text { The federal network } \\
\text { of nanotechnology } \\
\text { centers is located in } \\
11 \text { regions of the } \\
\text { country }\end{array}$ & $\begin{array}{c}\text { Participant: } \\
\text { International } \\
\text { Network for Small } \\
\text { and Medium-sized } \\
\text { Enterprises (INSME) }\end{array}$ \\
\hline
\end{tabular}

The strategic goal of creating a transfer network is to unite efforts of network participants for stimulating development of industrial cooperation, technology transfer and knowledge between industrial enterprises, scientific organizations, and higher educational institutions. The main tasks of the network are as follows:

- Promotion of innovations, assistance in the transfer of intellectual activity results, and the rights to use thereof among individuals and legal entities for subsequent implementation and/or commercialization thereof;

- Identifying industrial enterprises, scientific organizations, and higher educational institutions interested in technological cooperation and assisting them in overcoming barriers associated with the implementation of technology transfer projects;

- Search for partners for technological cooperation;

- Expansion of technological cooperation by involving a larger number of industrial enterprises in the production process;

- Identification and use of technological market niches for the implementation of innovative solutions and products (technologies);

- Development of the engineering services market;

- Creation of favorable conditions for the development of communications and the integration of small and medium-sized industrial enterprises into the economic system.

For instance, the Russian Technology Transfer Network (RTTN) employs the European technology transfer methodology and related four-stage business process [42] used by all RTTN member centers (Figure 2).

Stage 1. Revealing the client's potential for technology transfer;

Stage 2. Identification of technology profiles;

Stage 3. Search for technological cooperation partners;

Stage 4. Negotiating and concluding an agreement on technology transfer.

Potential opportunities for technological cooperation are discovered on the basis of applications. RTTN centers provide support for the primary contact between the client and the potential partner until the conclusion of an agreement on the transfer/technological partnership. 


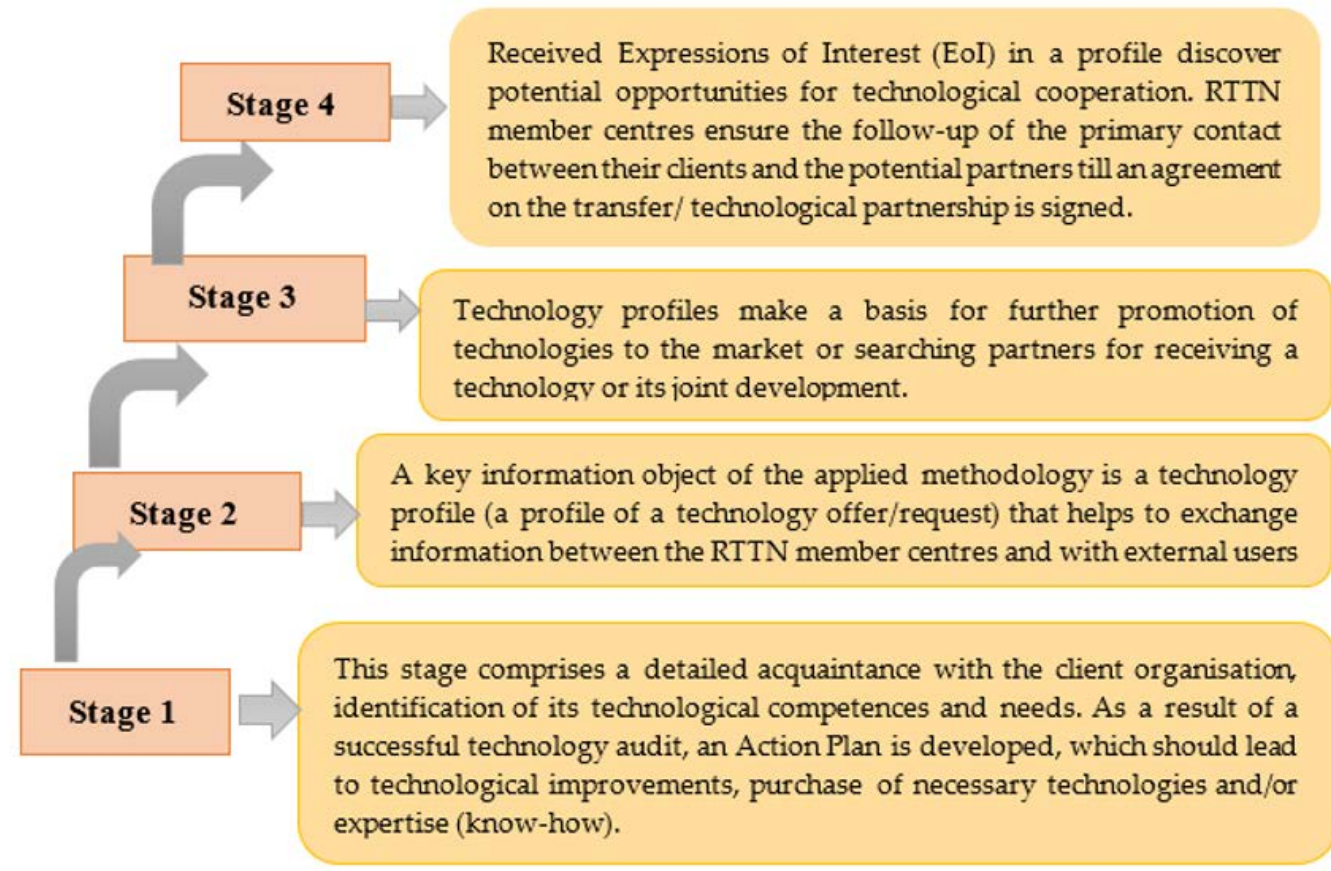

Figure 2. Business processes in the Russian Technology Transfer Network.

Here are the main functions of technology transfer network centers [43]:

1. Stimulating technology transfer (identifying companies interested in international technological cooperation and assisting them in the commercialization of technologies).

2. Information and consulting support on technological cooperation issues (standardization, certification, "verification of partners", attracting funding for scientific and technological projects).

3. Support for collaborations focused on industrial, scientific and technological cooperation.

4. Promotion of various financial instruments to support technology transfer projects within the network.

5. Consolidation of existing organizations professionally involved in the network technology transfer instead of creating new ones.

6. Formation of an environment for effective communication between all network participants, including innovative intermediaries.

7. Application of a specialized IT platform for interaction between network participants (coordinator, intermediaries, and companies) and provision of on-line services.

8. Fundraising to support network functioning, involving expenses for network coordination, methodological support of network participants, certification, promotion of the network, and attraction of new participants.

Being complex and multivariable process, technological transfer mechanisms are divided into three groups:

Technology transfer through licensing.

Technology transfer through the movement of human capital.

Technology transfer through cooperation in the field of R\&D and innovations.

Development of startup companies attracting third-party investors (venture funds, business angels) (start-up, spin-off, spin-on).

There are basic models for the development of technology transfer centers [44]:

(1) TTC is an independent legal entity, which may be founded by several organizations. This model is aimed primarily at promoting innovations in the regions by creating 
a favorable environment for establishing relations between research organizations, universities, and business entities.

(2) TTC is developed on the basis of a specific university or research organization, and is not an independent legal entity. The center activity is aimed exclusively at the results of research activity of a specific university and consists in servicing the university administration, representatives of firms, executive authorities, individual scientists, engineers, inventors, and entrepreneurs interested in commercialization of intellectual resources of the university.

(3) TTC is one of the key participants (actors) of the multi-level innovation ecosystem. Its role and functions will depend on the level of the ecosystem.

The conducted research has resulted in identifying the following technology transfer network models used in Russia:

1. The network as a tool to support implementation of innovative projects of transnational technology transfer, and European scientific and technological programs (e.g., Enterprise Europe Network). Various associations (networks) uniting organizations supporting innovative business (business incubators, innovation centers, and technoparks), created within the framework of national innovation programs are include into this group.

2. Technology Brokers Network is an association combining professionals in the field of technology transfer.

3. Specific (thematic) technology transfer networks created as special projects (e.g., Technology Transfer Center of RAS and RUSNANO).

4. Technology marketplaces are networks that implement the concept of open innovation uniting customers and providers of technology solutions (e.g., Russian Technology Transfer Network).

The next section will be devoted to the analysis of some cases on functioning of technology transfer centers at universities to identify the main barriers of technology transfer in innovative ecosystems in Russia at micro-, meso- and macro-levels.

\section{Results}

\subsection{An Analysis of Technology Transfer Models at Different Levels}

Evaluation of technology transfer efficiency allowed us to identify the most effective Russian TTC in accordance with the EEN performance indicators [43]. These are, primarily, technology transfer centers created on the basis of research institutes and universities with the status of National Research University. Let us consider the most effective and interesting practices.

The North-West Technology Transfer Center (NWTTC) is aimed at building a "conveyor" for serial creation and "growing" startups. The NWTTC initiates small innovative companies on the basis of scientific and technical developments to commercialize technology, license, or patents.

The Center for Technology Transfer and Commercialization (CTTC) at Novosibirsk State University (NSU) is to strengthen cooperation between NSU, high-tech business and government, to promote the participation of the University's strategic academic units in innovative development programs at state corporations, industrial enterprises and innovative companies. Implementation of the CTTC work plan is to facilitate the integrated development of the university's innovative ecosystem, synchronize work with what is happening in the region's innovation infrastructure, develop cooperation with high-tech businesses in the framework of training, implement applied research, and commercialize the results of intellectual property. A characteristic feature of the CTTC is a high level of networkization at NSU being a certified member of the Russian Technology Transfer Network (RTTN), the Southeast Asia Regional RTTN Center, an official participant in the partner network of the Agency of Technological Development and cooperation agreement in the creation and operation of the Eurasian Technology Transfer Network, an active user of such international technology transfer networks as Innoget, and Intellectual Property 
Intermediary (IPI, Singapore). This creates additional effective marketing channels to promote technological solutions to the markets of Russia, the CIS countries, and Western Europe and Southeast Asia countries.

The developed innovative infrastructure of National Research University of Electronic Technology (MIET) has become the basis for the formation of a whole cluster of small and large scientific and industrial enterprises that actively participate in the scientific and educational activities of the university and operate within the framework of common strategic priorities related to the promotion of domestic electronic products and developments in particularly important areas. A large-scale Technopolis Project has been implemented in cooperation with the Department of Investment and Industrial Policy of the city of Moscow.

When examining Russian technology transfer centers, the TTC of Tomsk State University (TSU) was chosen for a detailed analysis in creating a transfer system. Having used the entire capabilities of structural divisions, the TTC of TSU was able to ensure the balance of interests of state, business, and science. TSU was the first to implement the University 3.0 model among higher educational institutions, aimed at commercialization of knowledge and technology. Such a university manages intellectual property rights, forms an entrepreneurial ecosystem, promising technological markets, and turns into a platform for creating the country's economic superiority at the global level.

The university ecosystem of transfer and entrepreneurship is intended for developing desire and ability of students and university employees to introduce products into real production and production chains from industrial partners. Innovative projects and products are the tools for self-realization and achievement of employees, teams, collectives, and the university as a whole.

Here are entrepreneurship ecosystem building blocks:

- Communication with emergent entrepreneurs, resulting in the acquisition of entrepreneurial competencies by employees and students, and the creation of market companies;

- Service block associated with providing support for innovative activities of university departments, and the development of technological projects.

An emphasis is paid to:

- Creation of an entrepreneurial environment within the university, and a network of technology brokers;

- Creation of concept products for business-to-consumer (B2C) marketing to sell to manufacturers or invest (startup) as IP;

- Creation of packaged offers for business-to-business (B2B) marketing, and technology sales systems;

- Creation of facilities to sell university services to business, government, and international organizations.

An analysis of optimistic international experience in organizing TTC activities and an assessment of the functional state of Russian university centers for the provision of technology transfer services allowed us to identify the main barriers to the development of technology transfer in Russia (Figure 3). 

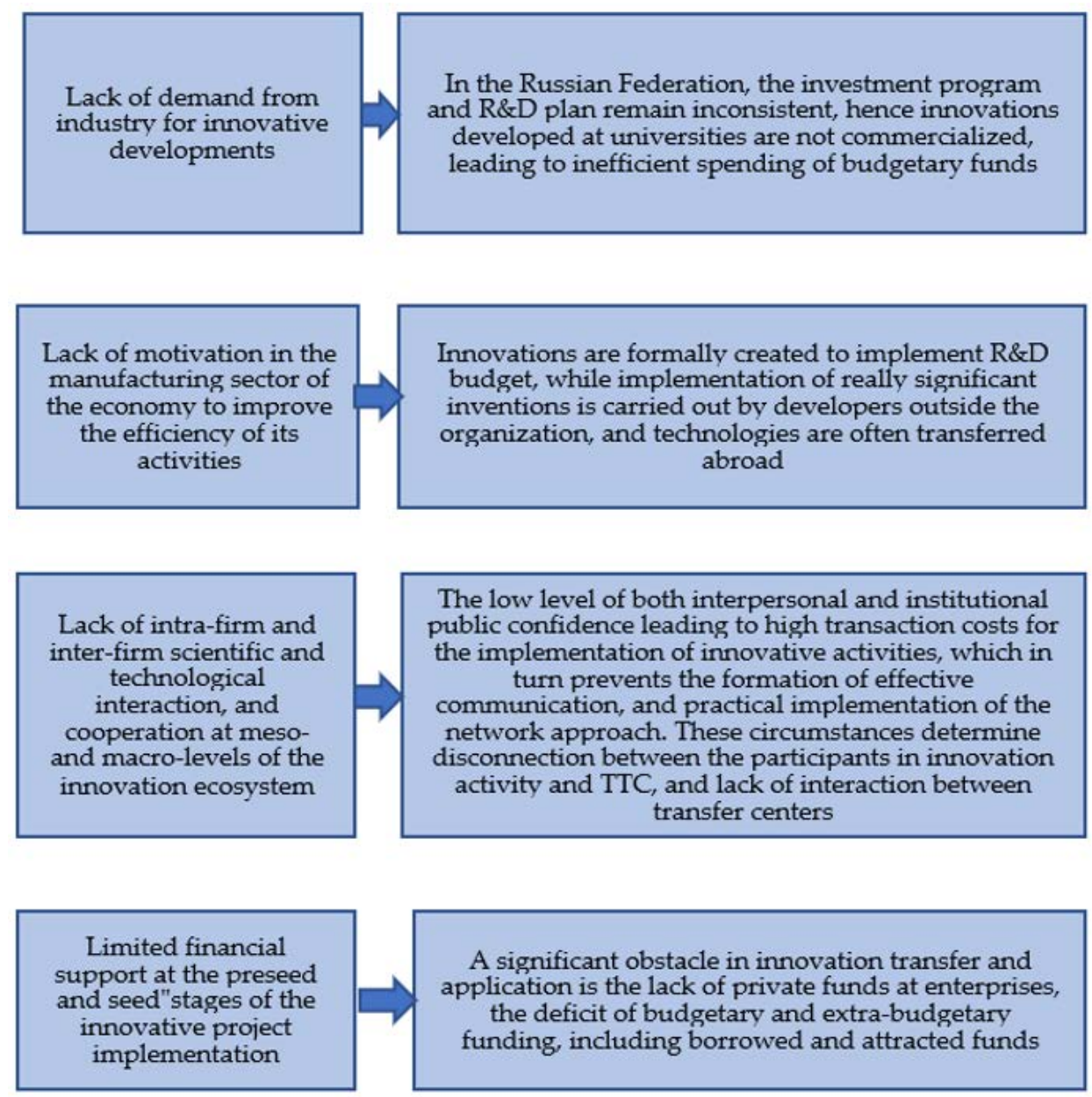

Figure 3. Barriers to technology transfer implementation in the Russian Federation. Source: own elaboration (updated based on [31]).

\subsection{Prospective Models for Creating a Network of Technology Transfer}

\subsubsection{Main Features of Innovation Ecosystems}

The research results have shown that insufficient interaction between individual technology transfer centers, namely, a low level of networkization, does not provide for building an effective technology transfer system. Here are feasible goals in organizing such interaction [31]:

1. Search for partners to implement innovative projects;

2. Selection of technological solutions based on generated technological requests;

3. Exchange of effective experience in technology transfer and implementation of innovative projects;

4. Promotion of the best world-class technological solutions in the Russian Federation;

5. Expert assessment of technological solutions in order to justify the choice of technologies, technological proposals, etc.

In this regard, it seems expedient to intensify activities in integrating individual technology transfer centers into a unified multi-level network. A model for an innovation ecosystem based on the principles of circular ecosystem can be used as a basic network model for technology transfer [44,45].

Our previous studies allowed us to identify the main features of innovation ecosystems [46]:

- Transboundary processes;

- Self-regulation, self-organization, and self-development; 
- Collaborative consumption models;

- Use of interdisciplinary knowledge and cross-sectoral technologies;

- Implementation of cross-industry projects at different levels;

- Use of infrastructure facilities and the resource base of regions;

- Unlimited project implementation in time: a project initiates the implementation of others, that is, the ecosystem is at the "succession" stage of the life cycle;

- Dynamism, flexibility, and openness;

- Collaboration based on partnership and trust;

- Balance of actors' goals and objectives;

- Cyclicality—new knowledge as exchange energy between actors.

Innovation ecosystem levels:

1. Micro-level corresponds to projects implemented within individual universities or research institutes. A technology transfer center can act as an economic agent.

2. Meso-level is a regional network of technology transfer centers that implements cross-industry projects based on an intra-industry or regional-territorial approach of interactions between economic entities.

3. Macro-level corresponds to projects of national, supranational, and economic systems. States can act as actors (participants) of such ecosystems.

Let us consider each level of the ecosystem in details.

\subsubsection{University's Innovation System (Micro-Level)}

Today, universities face a number of challenges in the context of increasing complexity of innovation processes.

First, the share of international and interdisciplinary knowledge production is constantly growing. Interdisciplinary innovations make new and increased demands for their organization and management.

Secondly, an increase in organizational and coordination complexity implies the need to use systemic innovative approaches.

Third, the nature of innovative knowledge exchange is moving towards complicated models of collaborative creativity and knowledge sharing.

The primary problem of the university is to increase the amount of knowledge accumulated by the innovation ecosystem, to process and transform information into knowledge, and to generate new information and new knowledge. Thus, the direct influence of the university on other actors in the ecosystem is the transfer of knowledge and technology. Technology transfer centers ensure the balance of cognitive energy exchange and the coherence of interaction between actors. Being an integrator of the innovation ecosystem, TTC is an "entry point" for the formation of new ideas, competencies, technological solutions, and the initiation of projects for the development and testing of new products. TTC should provide generating ideas for projects and specific tasks from the industry, such as the formation of resource support for the innovation process (analytical, predictive, infrastructural, investment, and financial). Accordingly, the objectives of TTC in the ecosystem model are as follows:

Initiation of ideas for projects;

Expert analysis, analytics, and prognosis;

Building relationships between project participants;

Analysis of information flows, constructing common information space structure;

project implementation and support;

Performance management and adjustment.

The actors (participants) of the university ecosystem are research laboratories and centers, startups, engineering centers acting as developers and suppliers of unique resources (Figure 3). Such outside players as industrial enterprises, financial and government structures act as customers of investment projects and suppliers of investment resources.

TTC established at Russian universities are presented in Table 2. 
Table 2. List of university technology transfer centers.

\begin{tabular}{|c|c|c|}
\hline № & Region & University \\
\hline 1 & Astrakhan Region & Astrakhan State Technical University \\
\hline 2 & The Republic of Bashkortostan & Bashkir State University \\
\hline 3 & Rostov Region & Don State Technical University \\
\hline 4 & The Kabardino-Balkarian Republic & $\begin{array}{c}\text { Kabardino-Balkarian State University named after } \\
\text { H.M. Berbekov }\end{array}$ \\
\hline 5 & The Republic of Tatarstan & Kazan (Volga region) Federal University \\
\hline 6 & Kaliningrad Region & Kaliningrad State Technical University \\
\hline 7 & Moscow & $\begin{array}{c}\text { National Research University of Electronic } \\
\text { Technology (MIET) }\end{array}$ \\
\hline 8 & Nizhny Novgorod Region & $\begin{array}{c}\text { Nizhny Novgorod State Technical University } \\
\text { named after R.E. Alekseev }\end{array}$ \\
\hline 9 & Omsk Region & Dostoevsky Omsk State University \\
\hline 10 & Penza Region & Penza State University \\
\hline 11 & Perm Krai & Perm National Research Polytechnic University \\
\hline 12 & Irkutsk Region & $\begin{array}{l}\text { Irkutsk National Research } \\
\text { Technical University }\end{array}$ \\
\hline 13 & Ryazan Region & Ryazan State Radio Engineering University \\
\hline 14 & Samara Region & Togliatti State University \\
\hline 15 & Chelyabinsk Region & South Ural State University \\
\hline 16 & Yaroslavl Region & P.G. Demidov Yaroslavl State University \\
\hline 17 & The Republic of Sakha (Yakutia) & M.K. Ammosov North-Eastern Federal University \\
\hline 18 & Nizhny Novgorod Region & Volga State University of Water Transport \\
\hline 19 & Nizhny Novgorod Region & $\begin{array}{l}\text { Lobachevsky State } \\
\text { University of Nizhny Novgorod }\end{array}$ \\
\hline 20 & The Republic of Mordovia & Ogarev Mordovia State University \\
\hline 21 & Saratov Region & Yuri Gagarin State Technical University of Saratov \\
\hline 22 & The Republic of Tatarstan & $\begin{array}{c}\text { Kazan National Research Technical University } \\
\text { named after A. N. Tupolev-KAI }\end{array}$ \\
\hline 23 & Arkhangelsk Region & $\begin{array}{c}\text { Northern (Arctic) Federal University named after } \\
\text { M.V. Lomonosov }\end{array}$ \\
\hline 24 & Krasnoyarsk Krai & Siberian Federal University \\
\hline 25 & Tomsk Region & Tomsk Polytechnic University \\
\hline 26 & Moscow & Lomonosov Moscow State University \\
\hline 27 & Moscow & $\begin{array}{l}\text { National Research Nuclear University MEPhI } \\
\text { (Moscow Engineering Physics Institute) }\end{array}$ \\
\hline 28 & Moscow & $\begin{array}{c}\text { National Research University of Electronic } \\
\text { Technology }\end{array}$ \\
\hline 29 & Krasnodar Krai & Kuban State Technological University \\
\hline 30 & Kursk Region & Southwest State University \\
\hline 31 & The Udmurt Republic & Udmurt State University \\
\hline 32 & Voronezh Region & Voronezh State University \\
\hline 33 & Altai Krai & Polzunov Altai State Technical University \\
\hline 34 & Irkutsk Region & Irkutsk State University \\
\hline 35 & Tomsk Region & Tomsk Polytechnic University \\
\hline
\end{tabular}


It should be emphasized that a key characteristic of successful innovation ecosystems is that knowledge moves everywhere between the actors in the ecosystem [47]. Thus, universities can help organize the free flow of innovation in the ecosystem through technology transfer centers by establishing relations using formal and informal channels described above (Figure 4).

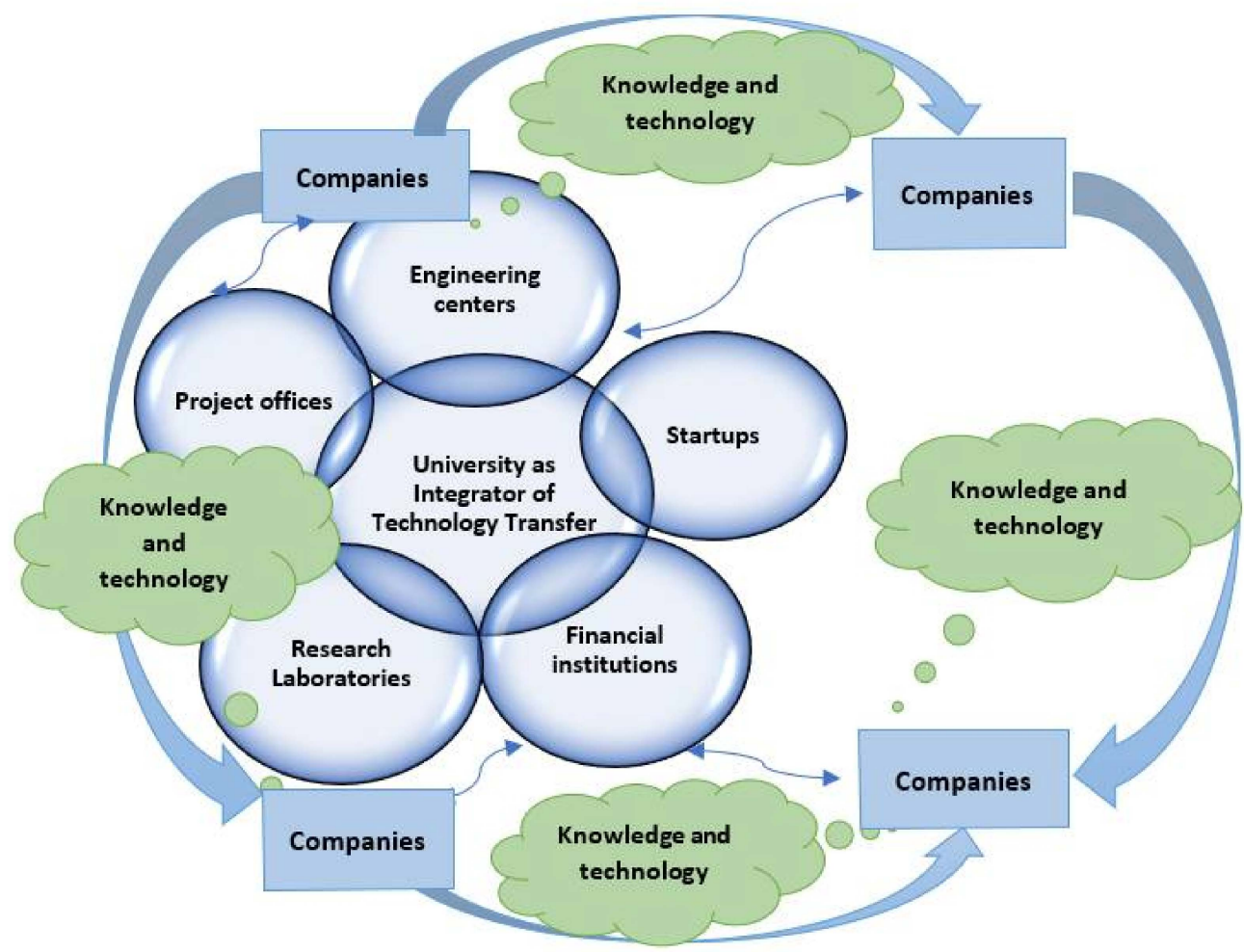

Figure 4. Innovation ecosystem (micro-level).

\subsubsection{Regional Innovation Ecosystem (Meso-Level)}

In the context of economic transformation, the role of universities as traditional centers for knowledge production is changing in the regional innovation ecosystem. The increasing complexity of interactions between different stakeholders poses significant challenges in the innovation activities process. In fact, universities have to balance between solving traditional and emerging challenges. As a result, an organizational model of universities has to be changed. Ensuring close interaction with the environment and the stakeholders is a key element of the university 4.0 concept.

The key parameter of the development vector of regional innovation ecosystem is knowledge playing the role of an energy source for the system (Figure 4). The innovative projects act as an integrator.

The main functions of universities within regional innovation ecosystem of TTC network are as follows:

1. Human resource development for high-tech businesses and industries.

2. Joint knowledge production for implementation of technological transfer projects being a driver of innovation. New expertise should reflect the cutting edge of research in a specific area so that enterprises and other stakeholders can cope with global challenges.

3. Promoting interdisciplinary research that requires systemic competencies and multilateral partnerships. Accordingly, the creation of interdisciplinary networks is a key organizational task for any innovative university. 
4. Specialization. Each university has its own development priorities (specific niches in large thematic areas with strengths) depending on the regional specifics it operates therein.

5. Interaction with external stakeholders to share knowledge. Universities should contribute to the creation of collaborative interdisciplinary innovation with other stakeholders. Knowledge exchange and collaboration with external partners is becoming as important as the sale and purchase of intellectual property objects [45].

The sources of intellectual energy of regional TTC network (meso-level) are knowledge generated at universities, and innovations. Universities have always reflected processes taking place in society; therefore, it is the university that can be an ecosystem springboard for innovations in technology, research, and management (Figure 5).

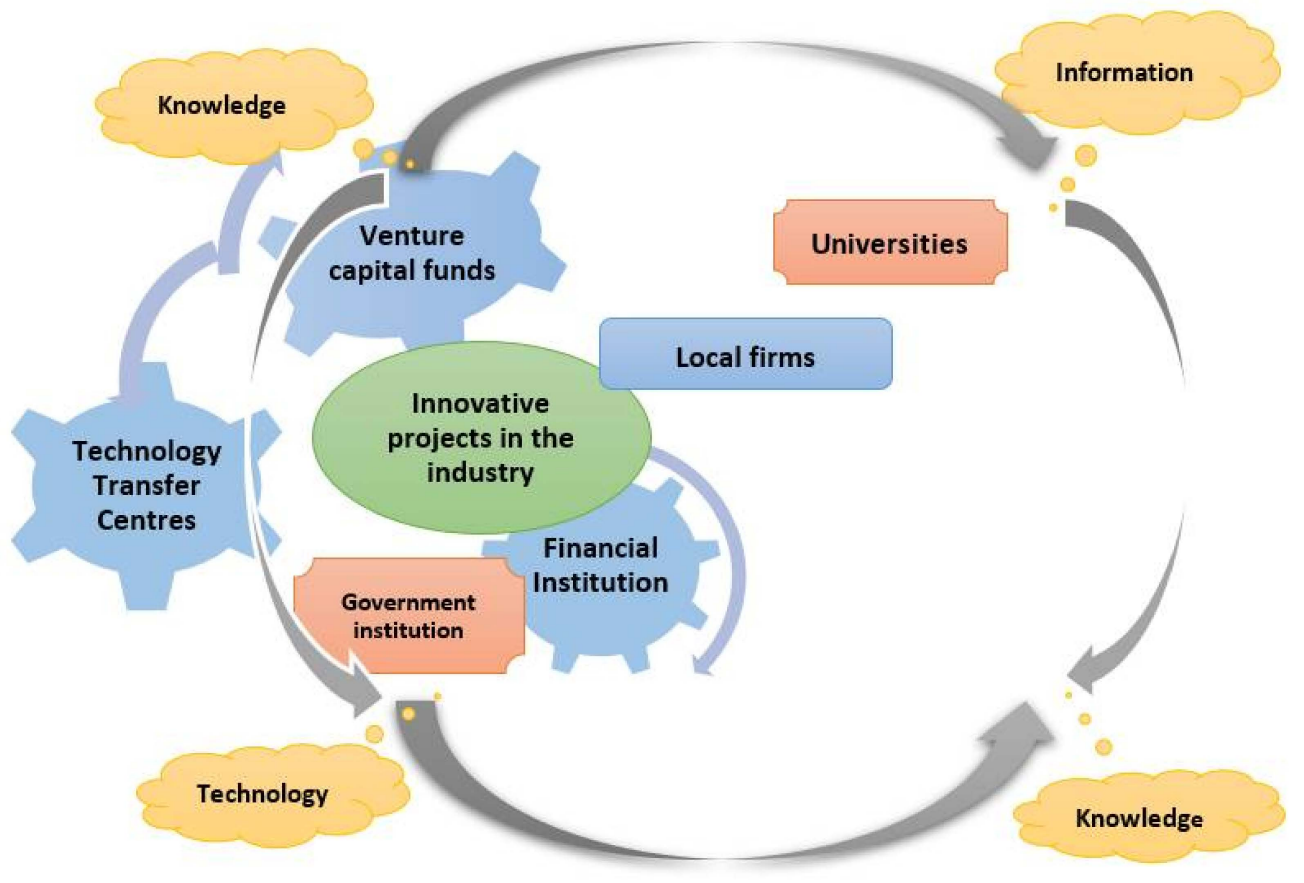

Figure 5. Innovation ecosystem (meso-level).

\subsubsection{The National Innovation Ecosystem (Macro-Level)}

The national innovation ecosystem indicates the level of collaboration between different participants (actors) of the system, which jointly form the country's capacities for the production of innovations.

Currently, the key role of universities due to a number of peculiarities thereof, provide opportunities to act as providers of innovations, linking education, science, and production in industries and regions of Russia, being a prerequisite for the innovative development of the country in general [46-48].

Universities are drivers of innovative processes in economic systems, creating conditions for achieving global technological leadership in Russia. However, it is necessary to develop mechanisms of research activities for the formation of new markets and technologies in vital areas, and improve tools for integration of innovations in real production, and commercialization of $R \& D$ results

Thus, one of the priority tasks is to create an effective unified network model for technology transfer on a national scale, consisting of university TTC, based on the ecosystem approach and the principle of cyclicality, taking into account the concept of open innovation. This concept is the evolution of technology transfer practice and methodology, resulting in emergence of new tools, namely, technology marketplaces (innovation accelerators), and crowdsourcing. Skolkovo Institute of Science and Technology (Skoltech) in cooperation with RUSNANO and Tomsk State University were the first to apply the ecosystem model of 
technology transfer in practice. IT platform appears to be the key tool for technology transfer network operation for effective interaction between transfer participants, digitalization of its key business processes, and the creation of industrial cooperation.

The national technology transfer network is the integration of meso-level nodes, and should include a common coordinating structure at the national level (e.g., the national office of regional technology transfer centers). This network structure should connect university technology transfer centers between thereof, with subjects of regional innovation ecosystems, technological partners, and strategic investors, that is, with all stakeholders (Figure 6).

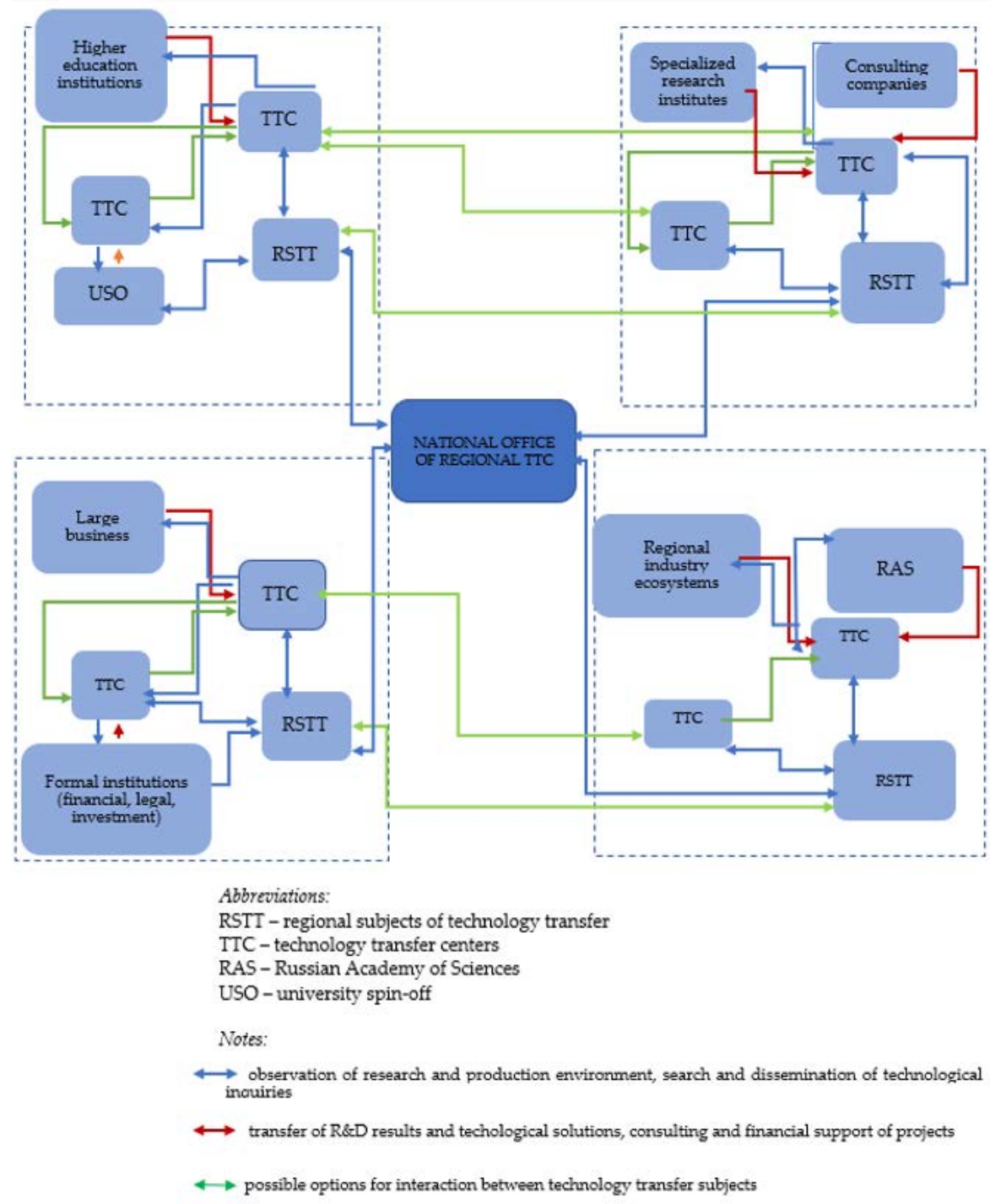

Figure 6. National technology transfer model. Source: own elaboration (adapted from [31]).

\section{Discussion and Conclusions}

The main purpose of the paper was to analyze existing barriers for technology transfer at different levels in Russia and propose prospective models and solutions for TT development taking into account the concepts of innovation ecosystem and open innovation. The research results contribute to the literature by providing a synthesis on the above concepts applied to the problem of technology transfer.

The research showed that Russian technology transfer market is mainly represented by isolated TTC aimed at commercializing the intellectual resources of a particular company. 
The authors suggest creating an effective unified network model for technology transfer on a national scale, consisting of university TTC, based on the ecosystem approach, taking into account the concept of open innovation. This concept is the evolution of technology transfer practice and methodology, resulting in emergence of new tools, namely, technology marketplaces (innovation accelerators), technology transfer platforms, network forms of open innovation, crowdfunding and crowdsourcing and other effective tools that allow to launch combined online-offline technology transfer operations.

Digital (technology) platforms appear to be the key tool for technology transfer network operation for effective interaction between transfer participants, digitalization of their key business processes, and the creation of industrial cooperation. Digital data and signals provide a common ground for handling diverse types of information [49].

The main functions of such platforms that help firms to embrace open innovation in different ways are as follows: information retrieval and publication, technology resources and services, technology exchange security, and matchmaking [50].

At the same time, an important role in the open innovation perspective is assigned to safety and transparency of transactions between interacting agents that in our view may be successfully provided by blockchain and smart contracts [51,52].

Indeed, as research showed the main problem is trust relationships or a lack thereof between the technology transfer participants. To solve this problem, it is required to address the third party for guarantees of transaction settlement. In risk management, the technology of the distributed register (blockchain) is being applied more actively, as it reduces the probability of fraud from dishonest participants and excludes the need for the third party by transferring its functions to the intelligent system [53].

In [54], the authors consider how blockchain technology can be utilized in order to overcome shortcomings of openness of innovation process or the "paradox of openness" (a tension between value creation and capture in joint innovation). These governance mechanisms should be incorporated into the platform technical architecture and allow standardizing the interactions within an innovation ecosystem. The potential of blockchain technology has been discussed by practitioners and scholars alike [55-57].

Meanwhile, all participants in the technology transfer, including individual enterprises, must have a sufficiently "mature" level of informatization and digitalization, since it is assumed that all information tasks will be performed using interactive tools.

In such conditions, the concept of socio-technical system analysis [58] is also especially relevant, emphasizing the integration of the technical system of the organization (tools and procedures) with the social system (roles and relationships between participants). An important part is for the modern participants in technological transfer in Russia to fully realize that such internal processes are both natural and necessary for the introduction of new technologies in an organization [59]. Moreover, it seems useful to integrate the open innovation concept into the dynamic capabilities framework [60-62]. Dynamic capabilities are the firm's ability to integrate, build, and reconfigure internal and external competences to address rapidly changing environments in which there is deep uncertainty [63].

Thus, a number of key areas can be proposed, the implementation of which will allow, in our opinion, to reduce (or completely neutralize) the impact of barriers to TT in Russia.

1. Initially, it is necessary to improve the legislative framework, where the main role should be assigned to the protection of intellectual property rights, as is the case in Western Europe and the United States. Strengthened intellectual property rights (IPRs) facilitate open innovation adoption. Thus, strong and certain IP protection and collaboration are complements in aiding the innovation process $[64,65]$.

2. Each side of technology transfer has a development strategy, and to achieve a successful result of innovation, a significant exchange of knowledge is required, on the one hand, and some ways and mechanisms to limit the exchange of other knowledge, on the other hand. Intellectual property rights help to deal with this controversy.

3. It appears necessary to develop a specialized program to support the technology transfer network to bring market demand closer to the capabilities of domestic scien- 
tific and industrial complex, and create an active circulation of intellectual rights and innovative developments primarily created through budgetary funding.

4. It is necessary to stimulate and accelerate the development of technology markets. It is necessary to develop regional and sectoral technology transaction markets connected to the nationwide network of technology transactions, to promote linkages and mergers between technology and capital markets, and to expand investment channels.

5. It is necessary to improve the quality of technology transfer services by developing standards for technology transfer services, improving market pricing mechanisms, creating a reliable specialized statistical system for the technology transfer services sector, improving the rules for identifying technology contracts and registration rules. Obviously, widespread use of common standards allows connectivity among diverse technology transfer participants.

6. Finally, there is a need to improve the infrastructure in the field of telecommunications with the outside world and within the country [66]. Scientific centers will be able to gain access to global knowledge, interact with foreign scientific centers and carry out joint work in real time. The exchange of data in an international format will greatly speed up the process of innovation generation, and consequently, it will lead to an improvement in the state of Russian technology transfer.

\section{Future Research}

The authors intend to conduct further research on a public-private partnership (PPP) financing mechanism for the development of technology transfer network. In innovation ecosystems, PPP allows to create a portfolio of unique technologies in areas where longterm competitive advantages for consistently high profits can be achieved. Eventually, the actors form an accelerated technology transfer on the basis of the accumulated reserves. The PPP mechanism is to be helpful for the development of digital and platform solutions in the field of technology transfer, for establishing effective communication channels between participants, and attracting additional investments for the implementation of projects, involving infrastructure crowdfunding.

Promising directions for future research should be focused on evaluating the proposed models from the perspective of individual ecosystem actors, taking into account such criteria as knowledge and technology exchange, implementation of innovations and market indicators, including both financial and non-financial indicators. Besides, this analysis can be carried out at different levels: individual participants, dyads and triads, networks, ecosystems, and the entire economy (e.g., in terms of the effectiveness of innovation support policies). From a meso- and macro-economic viewpoint, it will be promising to analyze the impact of the proposed models on the socio-economic development of regions and countries.

Author Contributions: Conceptualization, formal analysis, supervision, N.S.; writing—original draft preparation, collected data, data validation, performed the first data analysis, funding acquisition, L.G.; writing-original draft preparation, collected data, data validation, performed the first data analysis, funding acquisition, T.T.; writing — original draft preparation, collected data, data validation, D.L. collected data, data validation. All authors have read and agreed to the published version of the manuscript.

Funding: This research was funded by the RFBR grant No. 20-010-00470; an internal grant financed from the funds of the Plekhanov Russian University of Economics (Order No. 968 of 05.08.2020) on the topic "Formation of a financial mechanism to stimulate industry for the effective recovery of the national economy after the consequences of the pandemic, taking into account real imperatives and digital technologies".

Institutional Review Board Statement: Not applicable.

Informed Consent Statement: Not applicable.

Conflicts of Interest: The authors declare no conflict of interest. 


\section{References}

1. Nicodemus, T.; Egwakh, J.A. Technology transfer and competitive advantage: The managers' perspective. Eur. J. Bus. Manag. 2019, 11, 66-75. [CrossRef]

2. De Moortel, K.; Crispeels, T. International university-university technology transfer: Strategic management framework. Technol. Forecast. Soc. Chang. 2018, 135, 145-155. [CrossRef]

3. Villani, E.; Rasmussen, E.; Grimaldi, R. How intermediary organizations facilitate university-Industry technology transfer: A proximity approach. Technol. Forecast. Soc. Chang. 2017, 114, 86-102. [CrossRef]

4. Majidpour, M. International technology transfer and the dynamics of complementarity: A new approach. Technol. Forecast. Soc. Chang. 2017, 122, 196-206. [CrossRef]

5. McAdam, M.; Miller, K.; McAdam, R. University business models in disequilibrium—Engaging industry and end users within university technology transfer processes. RED Manag. 2017, 47, 458-472. [CrossRef]

6. Bradley, S.R.; Hayter, C.S.; Link, A.N. Models and methods of university technology transfer. Found. Trends En-Trepreneurship 2013, 9, 571-650. [CrossRef]

7. Chesbrough, H.; Bogers, M. Explicating open innovation: Clarifying an emerging paradigm for understanding innovation. In Open Innovation: New Frontiers and Applications; Chesbrough, H., Vanhaverbeke, W., West, J., Eds.; Oxford University Press: Oxford, UK, 2014.

8. Von Hippel, E. Democratizing Innovation; MIT Press: Cambridge, MA, USA, 2005.

9. Chesbrough, H.W. Open Innovation: The New Imperative for Creating and Profiting from Technology; Harvard Business School Press: Boston, MA, USA, 2003.

10. Zhang, F.; Tang, T.; Su, J.; Huang, K. Inter-sector network and clean energy innovation: Evidence from the wind power sector. J. Clean. Prod. 2020, 263, 121287. [CrossRef]

11. Gamidullaeva, L.A.; Tolstykh, T.O. Implementation of cross-industry projects on the principles of ecosystem as a new vector of innovative development. Innovations 2020, 8, 65-74.

12. Smorodinskaya, N.V. Networked innovation ecosystems and their role in dynamizing economic growth. Innovations 2014, 7 , 27-33.

13. Granstranda, O.; Holgersson, M. Innovation ecosystems: A conceptual review and a new definition. Technovation 2020, 90, 102098. [CrossRef]

14. Quinn, R.E.; Rohrbaugh, J. A Spatial Model of Effectiveness Criteria: Towards a Competing Values Approach to Organizational Analysis. Manag. Sci. 1983, 29, 363-377. [CrossRef]

15. Bell, M. Innovation Capabilities and Directions of Development; STEPS Working Paper 33; STEPS Centre: Brighton, MA, USA, 2009.

16. Etzkowitz, H.; Zhou, C. The Triple Helix: University-Industry-Government Innovation and Entreprneurship; Routledge: London, UK, 2018.

17. Perkmann, M.; Walsh, K. University-industry relationships and open innovation: Towards a research agenda. Int. J. Manag. Reviews 2007, 9, 259-280. [CrossRef]

18. Perkmann, M.; Walsh, K. Engaging the scholar: Three forms of academic consulting and their impact on universities and industry. Res. Policy 2008, 37, 1884-1891. [CrossRef]

19. Etzkowitz, H. Triple Helix Model. Innovations 2011, 4. Available online: https:/ / cyberleninka.ru/article/n/model-troynoy-spirali (accessed on 1 June 2021).

20. Roberts, E.B.; Malone, D.E. Policies and structures for spinning off new companies from research and development organizations. RED Manag. 1996, 26, 17-48. [CrossRef]

21. Roberts, E.B.; Peters, D.H. Commercial innovation from university faculty. Res. Policy 1981, 10, 108-126. [CrossRef]

22. Rosenberg, N.; Nelson, R.R. Merican universities and technical advance in industry. Res. Policy 1994, 23, 323-348. [CrossRef]

23. Rothaermel, F.T.; Thursby, M.C. Incubator firm failure or graduation? The role of university linkages. Res. Policy 2005, 34, 1076-1090. [CrossRef]

24. Rogers, E.M. Diffusion of Innovations; Free Press of Glencoe: New York, NY, USA, 1962.

25. Allen, T.J.; O'Shea, R.P. (Eds.) Introduction. In Building Technology Transfer within Research Universities: An Entrepreneurial Approach; Cambridge University Press: Cambridge, UK, 2014; pp. 1-10.

26. Fiyaksel, E.A.; Nazarov, M.G.; Islankina, E.A. European experience of cluster internationalization for improving national competitiveness. Innovations 2013, 2, 85-95.

27. Chesbrough, H. Open Business Model: How to Thrive in the New Innovation Landscape.; Harvard Business School Press: Cambridge, MA, USA, 2006.

28. Keith, E.M.; Reichman, J. International Public Goods and Transfer of Technology under a Globalized Intellectual Property Regime, 1st ed.; Cambridge University Press: Cambridge, UK, 2005; pp. 105-107.

29. Gee, S. Technology Transfer, Innovation and International Competitiveness; John Wiley \& Sons: New York, NY, USA, 1981.

30. Phillips, R. Technology Business Incubators: How Effective as Technology Transfer Mechanisms? Technol. Soc. 2002, 24, 299-316. [CrossRef]

31. Gavrilyuk, A.V. Technology Transfer Mechanisms to Foster Innovation. Ph.D. Dissertation of Candidate of Economics, University of Moscow, Moscow, Russia, 2019. 
32. Gamidullaeva, L.; Vasin, S.; Wise, N. Increasing small- and medium-enterprise contribution to local and regional economic growth by assessing the institutional environment. J. Small Bus. Enterp. Dev. 2020, 27, 259-280. [CrossRef]

33. Rogova, E.M. Business-incubators as elements of the technological transfer of Russian universities. Innovations $2014,7,55$.

34. Korolyova, E.V. The impact of technology and innovation support centers on the development of innovations in Russian regions. Vestn. N.-E. Fed. Univ. 2014, 2, 72-75.

35. Guribie, F.L.; Tengan, C. A Proposed Knowledge Management Implementation Framework for the Ghanaian Construction Industry. J. Build. Constr. Plan. Res. 2019, 7, 1-10. [CrossRef]

36. Ensign, P.C.; Lin, C.-D. Proximity, knowledge transfer, and innovation in technology-based mergers and acquisitions. Int. J. Technol. Manag. 2014, 66, 1. [CrossRef]

37. Chen, H.-M.; Yuan, Y.-H. Moderator Effects of Proactive Knowledge Transfer Among Knowledge Transfer Usefulness, Management, and Innovation: A Study of Knowledge Innovation Effective Model Construction. Int. J. Knowl. Manag. (IJKM) 2017, 13. [CrossRef]

38. Jones, N.B.; Mahon, J.F. Knowledge Transfer and Innovation; Routledge: New York NY, USA, 2018; 166p, ISBN 9781138712461.

39. Pinto, H. Connecting the Triple Helix space: Actor-network creation and institutionalisation of knowledge transfer offices. Triple Helix 2017, 4, 2. [CrossRef]

40. Dubickis, M.; Gaile-Sarkane, E. Transfer of know-how based on learning outcomes for development of open innovation. J. Open Innov. 2017, 3, 4. [CrossRef]

41. Dutta, S.; Lanvin, B.; Wunsch-Vincent, S. (Eds.) Global Innovation Index 2020. Who Will Finance Innovation? Cornell University: Ithaca, Greece; INSEAD: Fontainebleau, France; WIPO: Geneva, Switzerland, 2020.

42. Russian Technology Transfer Network (RTTN). 2016. Available online: https://rttn.ru/about-the-network (accessed on 2 February 2021).

43. Enterprise Europe Network (EEN). 2016. Available online: https:/ / een.ec.europa.eu/ (accessed on 13 February 2021).

44. Tolstykh, T.; Shmeleva, N.; Gamidullaeva, L. Evaluation of circular and integration potentials of innovation ecosystems for industrial sustainability. Sustainability 2020, 12, 4574. [CrossRef]

45. Tolstykh, T.; Gamidullaeva, L.; Shmeleva, N.; Woźniak, M.; Vasin, S. An assessment of regional sustainability via the maturity level of entrepreneurial ecosystems. J. Open Innov. Technol. Mark. Complex. 2021, 7, 5. [CrossRef]

46. Tolstykh, T.; Shmeleva, N.; Gamidullaeva, L. Elaboration of a mechanism for sustainable enterprise development in innovation ecosystems. J. Open Innov. Technol. Mark. Complex. 2020, 6, 95. [CrossRef]

47. Gamidullaeva, L.A. Inter-organisational network structures and knowledge diffusion through innovation intermediaries. Glob. Bus. Econ. Rev. 2019, 21, 756-776. [CrossRef]

48. Tolstykh, T.; Gamidullaeva, L.; Shmeleva, N. Universities as Knowledge Integrators and Cross-Industry Ecosystems: SelfOrganizational Perspective. SAGE Open 2021. [CrossRef]

49. Teece, D.J. Profiting from Innovation in the Digital Economy: Enabling Technologies, Standards, and Licensing Models in the Wireless World. Res. Policy 2018, 47, 1367-1387. [CrossRef]

50. An Online Platform for the UN Technology Facilitation Mechanism Independent Technical Assessment Findings. Available online: https:/ / sustainabledevelopment.un.org/content/documents/16505Full_Report_Online_Platform_Assessment.pdf (accessed on 20 June 2017).

51. Gamidullaeva, L.; Finogeev, A.; Vasin, S.; Deev, M.; Finogeev, A. The information and analytical platform for the big data mining about innovation in the region. Commun. Comput. Inf. Sci. 2019, 1083, 230-242.

52. Vasin, S.; Gamidullaeva, L.; Finogeev, A.; Parygin, D. Exploring regional innovation systems through a convergent platform for Big Data. In Proceedings of the 7th International Conference on System Modeling \& Advancement in Research Trends, Moradabad, India, 23-24 November 2018; IEEE: Moradabad, India, 2018; pp. 292-296.

53. Finogeev, A.; Vasin, S.; Gamidullaeva, L.; Parygin, D. Blockchain and Smart Contracts for Support the Interaction between the Actors in the Regional Innovation System. In Proceedings of the 2018 International Conference on System Modeling \& Advancement in Research Trends (SMART), Moradabad, India, 23-24 November 2018; pp. 27-31. [CrossRef]

54. Schmeiss, J.; Hoelzle, K.; Tech, R.P.G. Designing Governance Mechanisms in Platform Ecosystems: Addressing the Paradox of Openness through Blockchain Technology. Calif. Manag. Rev. 2019, 62, 121-143. [CrossRef]

55. Murray, A.; Kuban, S.; Josefy, M.; Anderson, J. Contracting in the Smart Era: The Implications of Blockchain and Decentralized Autonomous Organizations for Contracting and Corporate Governance; AMP: New York NY, USA, 2019. [CrossRef]

56. Werbach, K. The Blockchain and the New Architecture of Trust; MIT Press: Cambridge, MA, USA, 2018.

57. Catalini, C. How Blockchain Technology Will Impact the Digital Economy. 2017. Available online: https://www.law.ox.ac.uk/ business-law-blog/blog/2017/04/how-blockchain-technology-will-impact-digital-economy (accessed on 30 April 2021).

58. Trist, E. Organization Change: A Comprehensive Reader; Burke, W.W., Lake, D.G., Paine, J.W., Eds.; Jossey-Bass: San Francisco, USA, 2008; pp. 118-143.

59. National Academy of Engineering and National Research Council. Integrating New Tools into Information Work: Technology Transfer as a Framework for Understanding Success. In People and Technology in the Workplace; The National Academies Press: Washington, DC, USA, 1991. [CrossRef]

60. Teece, D.J.; Pisano, G.; Shuen, A. Dynamic Capabilities and Strategic Management. Strateg. Manag. J. 1997, 18, 509-533. [CrossRef] 
61. Teece, D.J.; Peteraf, M.A.; Leih, S. Dynamic Capabilities and Organizational Agility: Risk, Uncertainty, and Entrepreneurial Management in the Innovation Economy. Calif. Manag. Rev. 2016, 58, 13-35. [CrossRef]

62. Teece, D.J. Explicating Dynamic Capabilities: The Nature and Microfoundations of (Sustainable) Enterprise Performance. Strateg. Manag. J. 2007, 28, 1319-1350. [CrossRef]

63. Bogers, M.; Chesbrough, H.; Heaton, S.; Teece, D.J. Strategic Management of Open Innovation: A Dynamic Capabilities Perspective. Calif. Manag. Rev. 2019, 62, 77-94. [CrossRef]

64. Zobel, A.-K.; Balsmeier, B.; Chesbrough, H. Does Patenting Help or Hinder Open Innovation? Evidence from New Entrants in the Solar Industry. Ind. Corp. Chang. 2016, 25, 307-331. [CrossRef]

65. Teece, D.J.; 5G and the Global Economy: How Static Competition Policy Frameworks Can Defeat Open Innovation. Competition Policy International. Available online: https:/ / www.competitionpolicyinternational.com/5g-and-the-global-economy-howstatic-competition-policy-frameworks-can-defeat-open-innovation/ (accessed on 20 December 2019).

66. Kostin, K.B.; Khomchenko, E.A. Improving the efficiency of Russian entrepreneurship based on foreign experience in international technology transfer. Vopr. Innov. Ekon. 2021, 11, 729-744. [CrossRef] 